




\section{Comic Venus: Women and Comedy in American Silent Film Joshua}

Louis Moss

As Gerald Mast's seminal 1973 analysis, The Comic Mind: Comedy and the Movies, puts it, early American film comedy remains primarily defined by four figures: Charlie Chaplin, Buster Keaton, Harry Langdon, and Harold Lloyd (p. 22-23). Their work, understood in the popular imagination as the pinnacle of the form, reveals how comedic performances on screen developed in tandem, and often opposition, with the language of early film narrative (Kerr, 1975) (Sklar 1975) (Jenkins 1992) (Rapf \& Green, 1995). But this emphasis on the Silent Clowns also carries with it implicit omissions in understanding how humor and performance emerged in the first decades of popular American cinema. Dozens of other early film stars, performance styles, and hundreds of films remain either understudied or overlooked. This is especially problematic given the wide variety and popularity of films starring women comediennes that remain marginalized in academic discourse.

Kristen Anderson Wagner's Comic Venus: Women and Comedy in American Silent Film offers an important corrective. Building on the foundational scholarship of Kathleen Rowe, Rebecca Krefting, Robert Allen, Jennifer Bean, Vicki Callahan, Rob King, Bambi Haggins, and Alison Kibler, among others, Wagner performs a deep dive archival reexamination of silent era comediennes as complex areas of resistance. Wagner's impeccably researched approach places 
numerous films in conversation with fan cultures, movie magazines, and other archival secondary texts to show how early screen comediennes used unruly, aggressive, self-effacing, ribald, sexual, and other incongruous comedic satires of femininity to produce a collective critique. Despite appearing subservient, confused, low class, or self-deprecating, their screen performances and star personas challenged, as Wagner demonstrates, the "restrictive conceptions of femininity that would keep women socially and politically subordinate to men.” (p. 239).

As Wagner notes in her introduction, the lack of prior scholarship on silent film comediennes is partially related to the incomplete archive (p. 15). Chaplin, Keaton, Langdon and Lloyd's venerated films remain celebrated and well preserved. Conversely, much of the work of performers such as Mabel Normand, Colleen Moore, Gale Henry, Alice Howell, and Polly Moran, among many others, is either unrecoverable or exists only in incomplete form (p. 14). But this absence of study, as Wagner argues, is not simply due to a lack of surviving material. The dismissal of women's humor as an important or legitimate area of inquiry can be traced back to embedded biases in foundational humor theorists such as Schopenhauer, Bergson, and Freud (p. 2). In recent decades, interdisciplinary scholars working on humor theory, affect theory, feminist studies, and theories of embodiment have begun to address this marginalization. Vaudevillian gags, pratfalls, scenarios of misdirection, chase sequences, scenarios of incompetence, and spectacles of accident can be understood not only as comedic performances but also as sites of gender contestation and 
ideological renegotiation (Allen, 1991) (Jenkins, 1992) (Rowe, 1995) (Karnick \& Jenkins, 1995), (Trahair, 2007) (Paulus \& King, 2010) (Hennefeld, 2018).

Comic Venus builds on this work by examining not only how early film comediennes performed humor, but also how these performances subverted and critiqued many of the negative gender stereotypes they appeared to promote. Wagner begins chapter one by grappling with the central meta-question at work in the reception of female comic performances: can women be funny? The presumption of women as incapable of comedic agency required early screen comediennes to negate this anxiety through the performance of contra-feminine archetypes rooted in low class bawdiness and vulgar objectification. This technique allowed silent-era comediennes such as Marie Dressler, Colleen Moore, Alice Howell, Eva Tanguay, and Mabel Normand to slyly and subversively critique normative beauty standards while mitigating any claims to actual comedic intent (p. 36-37). But, as Wagner shows through detailed analysis of star personas and film magazines, these ribald, "homely" performances were carefully constructed comedic performances that paralleled the elaborate character constructions of Keaton, Lloyd, Langdon, and Chaplin. This performative mode reframed the female "gag" as one based on situation and premise rather than physical violence (p. 42). 
In chapter two, Wagner builds on the work of Jennifer Bean and Linda Mizejewski to argue that the "pretty/funny" dichotomy locates as the unruly nexus across numerous comic performances of the era (p. 77) (Mizejewski, 2017). Colleen Moore, Gale Henry, Constance Talmadge, and Polly Moran were just some of the comediennes that responded to the objectification of Mack Sennett's Bathing Beauties and beauty standards of the Ziegfeld Girls through satire and subversion of the artificial tropes of "beauty" itself (p. 83-87). Wagner performs detailed examinations of publicity photos and press releases in publications such as Moving Picture World, and films such as The Clinging Vine (1926), to show how these comediennes played "ugly" while simultaneously communicating a secret or hidden beauty, and thus agency, on behalf of the performer (p. 116-117). This gendered rhetoric of the "vulgar" allowed silent comediennes to neutralize embedded biases against women comediennes and spectatorial resistance to female comedic agency.

Wagner devotes chapters three and four to exploring how comediennes diffused and subverted anxieties of the freedoms of the "New Woman" (p. 184-185). Flapper Girl seduction cinema of the late 1910s and 1920s used sexuality, carnality, flirtation, and other forms of erotic agency by stars such as Clara Bow to navigate the tension between the legacy of the Victorian era and the emergence of women's liberation (p. 143-145). Unruly housewives lost in the city, such as Marie Dressler's Tillie in Tillie Wakes Up (1917) and fast talking shop-girls, such as Gloria 
Swanson's Tessie McGuire in Manhandled (1924), embodied the modern woman ethos through urban interactions and kinetic, energetic performances satirizing the confusing of changing gender mores (p. 191, 197). Ambition, confusion, lust, and wanderlust paralleled the physical danger and violence of their male slapstick counterparts while offering a critique of beauty standards as a mode of societal control (p. 150). Movie magazines and other press materials engaged in objectification, but these secondary texts also celebrated the behind-the-scenes agency, writing skills, and character constructions of Gale Henry, Mabel Normand, and Louise Fazenda, among others (p. 213). These secondary texts thus allowed fans multiple entrance points for decoding unruly comedic meanings. They opened spaces for what Wagner describes as an "alternative model of femininity" rooted in the agency of comic disruption, despite apparent objectification or the self-deprecation visible in the characters on screen (p. 131, pp. 224-226).

Impeccably researched and convincingly argued, Comic Venus provides a valuable academic road map for understanding how ideology and affect emerged in the various performative modes and star personas of the silent film comediennes. It joins recent work such as Linda Mizejewski and Victoria Sturtevant edited anthology, Hysterical!: Women in American Comedy (Austin: University of Texas Press, 2017), Steve Massa's Slapstick Divas: The Women of Silent Comedy (Georgia: BearManor Media, 2017), and Maggie Hennefeld's Specters of Slapstick 
and Silent Film Comediennes (New York: Columbia University Press, 2018), in bringing contemporary feminist theory into conversation with a reappraisal of early film archive studies. While some performance spaces, such as New York's Yiddish Cinema or the Chitlin Circuit, are perhaps underexplored, Comic Venus is strongest in its deft combination of textual analysis and in-depth readings of concurrent fan culture magazines such as Photoplay and Moving Picture World. Wagner shows how silent comediennes navigated objectification and agency through displays of physical desire and self deprecation, whether in the thrill rides of the machine age, comedy-of-errors cross dressing, or unruly erotic agency (p. 181-182). While they might perform confused, powerless, or unloved characters on screen, their humor actively worked to mitigate, and thus neutralize, the perceived dangers of the emancipated woman freed from domestic constraints by the modern world. 